\title{
A “ESCOLA REALISTA" FRANCESA: UMA INVENÇÃO DO TEATRO BRASILEIRO? (ANOS 1850-1860)
}

\author{
POLLETI, Daniel Nogueira ${ }^{1}$
}

RESUMO: Com esse artigo, nosso objetivo é não somente lançar luz sobre um período da história do teatro brasileiro, mas sobretudo propor uma nova interpretação para a escrita dessa história, que o recoloca no contexto de uma história global do teatro pelo estudo de um caso específico: a adoção do teatro de boulevard francês pelos homens de letras brasileiros nas décadas de 1850 e 1860, de onde o interesse em se pensar em termos de uma "transferência cultural". Se a dramaturgia dita realista prosperou no Brasil por alguns anos, foi porque ela encontrou na sociedade brasileira da época um conjunto de fatores que fizeram dela viável, que incluem as transformações sociais da época, o alargamento do mercado editorial e de diversões que resultam, por sua vez, em desequilíbrios do campo literário e mudanças na concepção do trabalho intelectual. Os homens de letras, de seu lado, aproveitaram a plasticidade desse produto cultural e o ressignificaram dentro dos processos que estão ocorrendo dentro de seu próprio campo e de uma certa tradição nacional. Assim, eles criaram uma história do teatro nacional dentro de uma história global e se posicionaram em relação ao seu passado em ruptura e, ao mesmo tempo em continuidade.

PALAVRAS-CHAVE: teatro brasileiro; teatro de boulevard; Ginásio Dramático; transferência cultural.

\section{« L'ÉCOLE RÉALISTE » : UNE INVENTION DU THÉÂTRE BRÉSILIEN ? (ANNÉES 1850-1860)}

RÉSUMÉ : Dans cet article, notre but est de non seulement comprendre une période de l'histoire du théâtre brésilien, mais, surtout, proposer une nouvelle interprétation pour l'écriture de cette histoire, qui remet le théâtre brésilien dans le contexte d'une histoire globale du théâtre par l'étude d'un cas spécifique : 1'adoption du théâtre de boulevard français par les hommes de lettres brésiliens dans les décennies 1850 et 1860 , d'où l'intérêt du concept de « transferts culturels ». Si la dramaturgie dite réaliste a prospéré au Brésil pendant quelques années, cela n'a pas été possible qu'en fonction d'un ensemble de facteurs qui l'ont faite viable, ce qui inclut les transformations sociales de l'époque,

\footnotetext{
${ }^{1}$ Daniel Polleti é doutorando no Centre d'histoire culturelle des sociétés contemporaines, Université Paris-Saclay. e-mail : danielpolleti@msn.com.
}

Jangada| ano 9, nr. 17, jan/jun, 2021 | ISSN 2317-4722 


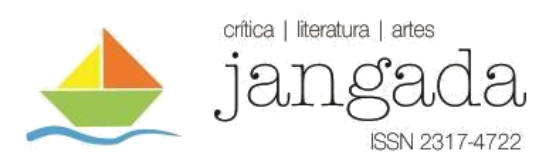

l'élargissement du marché éditorial et de divertissements qui occasionnent, de leur côté, des déséquilibres dans le champ littéraire et un changement dans la conception du travail intellectuel. Les hommes de lettres profitent de la plasticité de ce produit culturel et vont le resignifier dans les processus qui ont lieu dans son propre champ et dans le contexte d'une certaine tradition nationale. Ainsi, ils créent une histoire du théâtre national au sein d'une histoire globale et se positionnent par rapport à leur passé en même temps en rupture et dans la continuité.

MOTS-CLÉS : théâtre brésilien ; théâtre de boulevard ; Ginásio Dramático ; transfert culturel.

Em 1855, o Rio de Janeiro ganharia uma nova empresa teatral, criada para ocupar o teatro de São Francisco. Dirigida pelo empresário Joaquim Heleodoro Gomes dos Santos, que contratou o francês Emílio Doux (1798-1876) como ensaiador, a companhia teria como objetivo "estabelecer o verdadeiro e apurado gosto pela representação do vaudeville e da comédia" (Diário do Rio de Janeiro, 05/03/1855). A estreia teve lugar no dia 12 de abril no teatro rebatizado Ginásio Dramático, em referência ao Gymnase dramatique parisiense, com duas peças, O Primo da Califórnia, imitação de Joaquim Manuel de Macedo (1820-1882) de uma peça francesa, e Une faute, de Eugène Scribe (1791-1861). Este foi o autor mais representado durante os primeiro seis meses da nova empresa, que encenou cerca de 25 títulos de sua lavra - o que não era exatamente uma novidade, pois uma companhia francesa já o havia apresentado ao público carioca nos anos 1840 (SCANDAROLLI, 2016). A importância do Ginásio para a história do teatro brasileiro reside principalmente no fato de que, alguns meses mais tarde, provavelmente estimulado pelos elogios da imprensa e pelas esperanças de uma parte da jovem intelectualidade local, descontente com a falta de renovação do repertório da principal companhia teatral da corte, dirigida por João Caetano dos Santos (1808-1863) e que ocupava o teatro São Pedro de Alcântara, Joaquim Heleodoro começa a montar as peças dos autores mais em evidência em Paris na época, que formam aquilo que ficará conhecido como "escola realista.” Mais tarde, alguns jovens autores vão se aproximar desse repertório e, diagnosticando uma suposta "decadência" do teatro nacional, vão proclamar a abertura de um novo caminho para a "regeneração" ou mesmo para a "criação" das artes cênicas nacionais (SILVA, 2000, p. $10)$.

Para Sébastien Rouzeaux (2012), a aparição do Ginásio pode ser interpretada como um momento de um longo processo que ocorre entre 1830 e 1880, durante o qual a unidade intelectual e política do império se fissura pouco a pouco, de maneira que o modelo fundador 


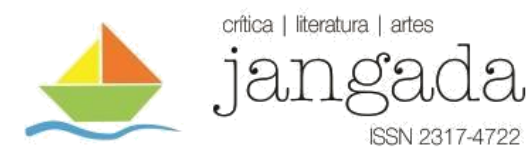

do escritor orgânico tende a ruir gradualmente pois, de um lado, o sistema do mecenato e de favores que ligava o homem de letras ao Estado imperial se mostra incapaz de satisfazer às ambições de um meio literário em expansão e, de outro lado, o desenvolvimento do mercado editorial e do público leitor abre novas possibilidades econômicas e de consagração para os candidatos a uma carreira literária. Aparecem, assim, novas representações concorrentes da figura do homem de letras, com lógicas heterônomas de consagração, o que permite que diferentes estratégias de distinção coexistam. No que se refere particularmente à dramaturgia, o líder da geração que começa a aparecer nos anos 1850, José de Alencar² (1829-1877), encontra em Joaquim Heleodoro - que teria um papel homólogo àquele de certos editores para o romance e a poesia, como Baptiste-Louis Garnier (1823-1893) e Francisco de Paula Brito (1809-1861) - um aliado capaz de ajudar os jovens autores a darem uma nova direção para a cena brasileira, como nós vemos em uma carta escrita pelo autor: "Joaquim Heliodoro, em sua modesta posição de empresário de um pequeno teatro, sem presunções literárias, [...] era então para os autores dramáticos o que veio a ser Garnier para os escritores.” (apud Rozeaux, 2012, p. 738).

Mas qual era esse modelo dramatúrgico que esses autores chamavam de "escola realista"? Por este nome, nós devemos entender o teatro burguês francês do Segundo Império cujos principais representantes eram Alexandre Dumas fils, Émile Augier e Victorien Sardou, aquilo que Hanna Hashem (2015) chama de "dramaturgia do savoir-vivre". Mas o que esses jovens autores brasileiros encontravam nessa literatura, além de ser a última novidade de Paris, para que eles quisessem aclimatá-la? Talvez uma abordagem comparativa sobre a recepção dessa dramaturgia nos dois lados do Atlântico possa nós ajudar a esclarecer esse ponto.

\section{O TEATRO BURGUÊS FRANCÊS E SUA RECEPÇÃO PELA ELITE INTELECTUAL}

\section{BRASILEIRA}

Com uma terminologia que oscila entre "drama burguês", "comédia séria" ou - expressão mais utilizada no Brasil - "comédia realista", esse gênero dramático se baseia na realidade contemporânea dos espectadores. Trata-se de um teatro figurativo e é um gênero de imitação, mais frequente em prosa, que mistura diferentes tonalidades (BRUNET, 2005, p. 40-41). O

\footnotetext{
${ }^{2}$ Sobre a relação do autor com o teatro, ver FARIA, 1987.

Jangada| ano 9, nr. 17, jan/jun, 2021 | ISSN 2317-4722

55 | Pág in a
} 


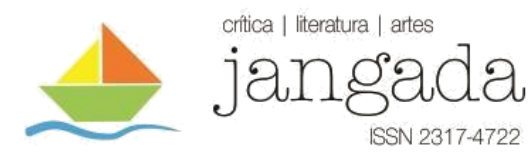

fracasso de Les Burgraves, de Victor Hugo, e o sucesso de Lucrèce, de François Ponsard, em 1843, marcam uma nova orientação para o drama francês após mais de uma década de hegemonia do Romantismo. De início, com uma efêmera restauração clássica representada pela "École du bon sens", e, em seguida, com a estreia de La Dame aux camélias, de Dumas fils, em 1852, fato que inaugura, segundo a fórmula de Henry Becque, um "período de espírito" que sucede ao "período da imaginação". Comédia e drama se misturam e se confundem sob o nome de "peça", realizando, ao mesmo tempo, os preceitos morais do drama burguês do século XVIII

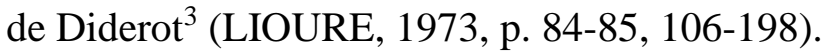

Gengembre (1999, p. 141-143) coloca o teatro de boulevard na continuação das receitas criadas por Scribe, que progressivamente se afirma entre as salas subvencionadas e o teatro de vanguarda, de um lado, e o teatro mais claramente popular, de outro. Notemos que o Gymnase dramatique de Paris foi, antes de se abrir para a dramaturgia de Dumas fils, Augier e Sardou sob a direção de Adolphe Lemoine-Montigny (1806-1880) (Cf. HASLÉ, 2020), o teatro de predileção de Scribe, onde ele representou 182 peças (YON, 2000, p. 72) ${ }^{4}$. Sendo assim, o Ginásio Dramático brasileiro seguiu, passo a passo, uma das tendências do teatro parisiense representada particularmente por um estabelecimento. E a adoção do nome da casa parisiense parece indicar de maneira consistente que isso foi uma estratégia adotada conscientemente por Joaquim Heleodoro, que viu um nicho do mercado inexplorado e que o distinguia da companhia de João Caetano no teatro São Pedro - uma boa aposta, pois ele efetivamente respondeu a uma demanda de uma parte do público. No entanto, a quase completa ausência de dados biográficos sobre o empresário não nos permite reconstituir a concepção do seu projeto - mas ele sem dúvida encontrou uma consonância de interesses com uma parte da jovem intelectualidade brasileira, que fez dessa dramaturgia alguma coisa parecida a um movimento literário.

É interessante observar como esse momento é tratado pela historiografia em cada um dos dois países. Na França, essa dramaturgia, espremida entre as audácias românticas, de um lado, e as inovações das vanguardas, de outro, tendo quase desaparecido dos palcos de nossos dias, enquanto que o vaudeville, que lhe é contemporâneo, continua a ser representado tanto nas salas mais renomadas quanto no circuito comercial, recebe pouca atenção dos pesquisadores, que a colocam normalmente como uma etapa intermediária da evolução dramatúrgica francesa ou sob a etiqueta, que frequentemente tem conotações pejorativas, de

\footnotetext{
${ }^{3}$ Sobre a questão da moralidade no teatro de Diderot, cf. SANTANA, 2017.

${ }^{4}$ Para a relação de Scribe com os três outros autores, cf. YON, 2010.
} 
“teatro de Boulevard”. Se Gengembre (1999, p. 144-145) considera que "a comédia realista é sem dúvida a forma mais durável" desta categoria dramatúrgica e "aparece como a maior realização do teatro oficial e uma das tendências mais marcantes do Boulevard ${ }^{5 \%}$, ele coloca a dramaturgia de Dumas fils e Augier como o último momento do teatro romântico e afirma que "Alexandre Dumas fils adapta o romantismo aos costumes de seu tempo" (GENGEMBRE, 1999, p. 214), antes de entrar na discussão sobre o drama naturalista. Lioure (1973, p. 106-108), por sua vez, abre seu capítulo sobre o drama naturalista com uma rubrica dedicada ao "período de espírito", o que dá a entender que esta dramaturgia é um momento de inflexão em direção ao naturalismo. De qualquer maneira, a impressão dada pelo discurso historiográfico é de um período de contornos e características pouco definidas, como um momento de transição na evolução do drama e talvez mesmo de menor valor artístico e literário - por exemplo, mesmo um pesquisador que estuda essa dramaturgia, justifica o seu trabalho sobre a obra de Émile Augier com a afirmação de que, "apesar de sua evidente falta de originalidade, ou mesmo por conta disso, [ela] pode nos introduzir a um conhecimento mais íntimo e mais vivo do que foi a sociedade de seu tempo ${ }^{6 ”}$ (DANGER, 1998, p. 7).

Nós encontramos uma história completamente diferente na historiografia brasileira. $\mathrm{O}$ "realismo" teatral é um capítulo obrigatório de pleno direito da história do teatro - e não apenas da dramaturgia - brasileiro. E um período dos mais brilhantes, visto retrospectivamente como uma fase durante a qual a competição entre o Ginásio e o São Pedro teria resultado em um verdadeiro desabrochar da literatura dramática. Segundo João Roberto Faria, “a inauguração do teatro por Joaquim Heleodoro Gomes dos Santos desencadeou uma estimulante rivalidade com a companhia de João Caetano", ao passo que "um forte entusiasmo tomou conta de uma boa parcela do público e dos intelectuais” (In FARIA e GUISNBURG, 2012, p. 159), de tal maneira que "o período iniciado com a criação do Ginásio Dramático foi um dos mais férteis de nossa literatura dramática" (FARIA, 2001, p. 138).

No entanto, o que nós achamos problemático é o uso da expressão "escola realista", sobretudo quando usada em referência à dramaturgia francesa, que aparece frequentemente nos trabalhos de pesquisadores brasileiros para se referir a um grupo de autores no qual podemos incluir Dumas fils, Augier, Sardou, Théodore Barrière, Octave Feuillet, Lambert-Thiboust e

\footnotetext{
5 “[...] la comédie réaliste est sans doute la forme la plus durable [...] apparaît à la fois comme le fait majeur du théâtre officiel et comme l'une des tendances les plus marquantes du Boulevard."

6 “[...] malgré son évidente absence d'originalité, ou plutôt en raison même de cela, peut nous introduire à une connaissance plus intime et plus vivante de ce que fut la société de son temps."
}

Jangada | ano 9, nr. 17, jan/jun, 2021 | ISSN 2317-4722

57 | Pá g i n a 


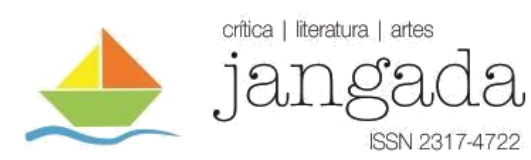

outros. Nós encontramos afirmações como "a nova escola realista francesa quer [...] reformar a sociedade" (SOUTO-MAIOR, 2004, p. 306), ou que os jovens "dramaturgos [são] adeptos da escola realista francesa" (REIS, 2013, p. 64). Nos parece precipitado falar de uma "escola" se pensarmos no sentido literal da palavra, como uma relação de mestre e discípulo, com a transmissão de um ensinamento - ou mesmo de um "movimento" - como um conjunto de escritores e de obras que apresentam uma unidade estética e ideológica, unidos em torno de um objetivo comum proclamado por manifestos - em referência a esses autores. Sobre a tríade Augier-Dumas fils-Sardou, Hanan Hashem escreve que seus nomes

estavam fortemente ligados, pois eles se tornam no Segundo Império os mestres da cena francesa. Eles se conheciam, se admiravam e se invejavam, também. Além disso, um vínculo de vizinhança os unia, pois cada um deles possuía um palacete em Marly-le-Roi, [de tal maneira que] os três autores merecem ser estudados juntos, não com um objetivo comparatista, mas buscando explorar a matéria dramática que eles ofereciam ao público do Segundo Império ${ }^{7}$ (HASHEM, 2015, p. 11).

Daí a falar em "escola" nos parece um passo exagerado, ainda mais se nós juntarmos toda uma série de autores da época, pois isso seria dar uma homogeneidade e uma coesão a um conjunto de dramaturgos que não formam um verdadeiro grupo, apesar de algumas características comuns, como a habilidade como artesãos dramáticos e a adesão à moral burguesa convencional do Segundo Império.

Mas nós não podemos dizer que a "escola" realista foi uma invenção da historiografia brasileira, pois os próprios homens de letras que se juntaram em torno do Ginásio utilizavam a expressão para se referirem ao repertório francês da época e fizeram dela o modelo para levantar o teatro nacional. Dessa forma, eles pegaram uma parte da dramaturgia francesa, a colocaram sob uma bandeira única capaz de servir de referência e se "filiaram" - um pouco como se os filhos tivessem criado seus pais. Machado de Assis (2008, p. 119), por exemplo afirmava pertencer à "escola realista". José de Alencar é outro que não escondia sua "filiação":

7 “[...] étaient fortement liés de leur vivant, puisqu'ils deviennent sous le Second Empire les maîtres de la scène française. Ils se connaissaient, s'admiraient et se jalousaient aussi. Un lien vicinal les unissait encore puisque chacun d'eux possédait un château à Marly-le-Roy [...] les trois auteurs méritent d'être étudiés aujourd'hui conjointement, non pas dans un objectif comparatiste mais avec la volonté d'explorer la matière dramatique qu'ils offrent au public du Second Empire."

Jangada | ano 9, nr. 17, jan/jun, 2021 | ISSN 2317-4722

58 | Pá g i n a 


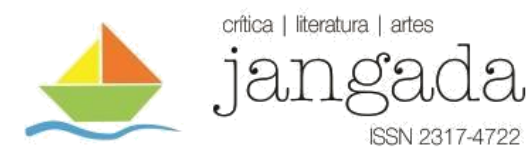

Não achando pois na nossa literatura um modelo, fui buscá-lo no país mais adiantado em civilização, e cujo espírito tanto se harmoniza com a sociedade brasileira; na França. Sabe, meu colega, que a escola dramática mais perfeita que hoje existe é a de Molière, aperfeiçoada por Alexandre Dumas Filho, e de que a Question d'Argent é o tipo mais bem acabado e mais completo. (In FARIA, 2001, p. 471)

Mas não é somente a dramaturgia que lhe serve de modelo, o público francês também serve de exemplo para o público brasileiro que, segundo Alencar, não está preparado para o repertório da nova escola - é preciso educá-lo, portanto:

Os franceses vão ao Ginásio de Paris ver uma dessas comédias; e no meio do mais profundo silêncio escutam o ator que só depois de cinco minutos diz uma palavra; acompanham a cena que se arrasta vagarosamente; aplaudem essa naturalidade com muito maior entusiasmo do que esses lances dramáticos tão cediços, que se arranjam com duas palavras enfáticas, e uma entrada imprevista.

Mas o nosso público, não por sua culpa, sim pela nossa e pela de todos, não está ainda muito bem disposto a favor desta escola, ele prefere aquilo que se representa seja fora do natural; e só aplaude quando lhe chocam os nervos, e não o espírito, ou o coração. (In FARIA, 2001, p. 471)

No entanto, a primeira peça de Alencar a subir ao palco, em 1857, O Rio de Janeiro, verso e reverso, foi um sucesso pois "o público ilustrado foi mais benévolo que [ele] esperava e merecia” (In FARIA, 2001, p. 471).

Ora, o que esses autores fizeram, imaginando uma "escola realista", foi criar uma paternidade comum transatlântica que os distinguia dentro de seu próprio espaço literário nacional, ao mesmo tempo que eles criavam uma homologia de interesses entre eles, um empresário e uma parte do público, o público ilustrado - e, sobre este ponto, notemos que o Ginásio Dramática tinha apenas 256 lugares. Essa alteridade criada em oposição ao teatro São Pedro se manifesta, em primeiro lugar, pela oposição entre duas "escolas", a romântica e a realista, esta sendo, nas palavras de Machado de Assis (2008, p. 119), "mais sensata, mais natural e de mais iniciativa moralizadora e civilizadora." Além disso, há uma oposição temporal, no sentido de que o realismo seria a "escola moderna", em oposição ao repertório da 


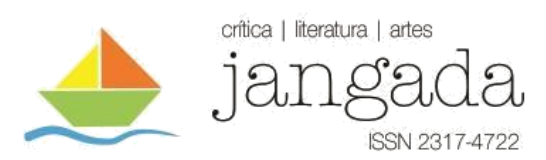

trupe de João de Caetano, onde predomina as tragédias neoclássicas ao lado de dramas e, sobretudo, melodramas românticos - esta outra "escola" que, segundo Quintino Bocaiuva (In Faria, 2001, p. 456), teria como resultado “a exacerbação dos espíritos e a corrupção dos costumes, a extravagância das ideias e a deturpação dos sentimentos”. Nesse sentido, Joaquim Heleodoro teria aberto uma nova era para o teatro brasileiro e teria mostrado o caminho para a necessária, segundo a pena de muitos literatos da época (SOUZA, 2002, p. 22), regeneração do teatro nacional, como nós lemos em uma carta não assinada publicada no Correio Mercantil em 23 de março de 1861:

Em pouco mais de cinco anos de tarefa laboriosa, [...] [Joaquim Heleodoro] conseguiu resultados que ainda duram. Abriu para a cena uma nova era, iniciando a escola moderna entre nós contra o paladar estragado da plateia; e se não pôde educar-lhe completamente o gosto com as exibições artísticas do seu teatro, que obtinham diariamente os sufrágios da imprensa, esclareceu-o muito aqui e acolá, desbravando com esse trabalho de roteação o caminho do futuro que outros deviam trilhar.

Assim, como observa João Roberto Faria (2001, p. 142):

Ao contrário do romantismo, que se caracterizou pela dispersão de forças, o realismo teatral no Brasil constituiu-se como um movimento coeso, que nasceu e cresceu com base em conceitos claramente definidos.

Um grupo de intelectuais e escritores, vários artistas de prestígio e uma casa de espetáculos [e, nós acrescentaríamos, um público] estiveram ligados por cerca de dez anos em torno de objetivos comuns e estimulados por uma mesma maneira de conceber o teatro.

Nós observamos a inversão que se opera no Brasil em relação ao modelo dos homens de letras, a França, onde podemos falar efetivamente de um movimento romântico, mas não de uma escola realista. Julgando pelas opiniões dos escritores brasileiros, eles encontram em Joaquim Heleodoro aquilo que João Caetano não pôde lhes oferecer. Este era desde há muito tempo acusado de se preocupar somente com sua glória pessoal, o que tornaria a criação do teatro nacional impossível, pois não haveria uma convergência de interesses entre os diversos agentes que participam da criação do espetáculo. É a ideia expressa no texto de Araújo Porto- 


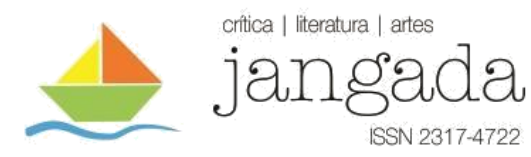

Alegre publicado na revista Guanabara em 1852, intitulado "Nosso Teatro Dramático". Segundo o autor, o teatro brasileiro "vive de oscilações, ora levantando parcialmente em algum de seus elementos artísticos, conforme a capacidade do indivíduo que a ele se associa, e conforme o maior ou menor grau do seu talento," mas “não há no seu todo uma marcha regular, um caráter progressivo," estando o palco submetido a "uma ambição sem glória nacional", e a "uma política toda individual” (In FARIA, 2001, p. 365). Para Porto-Alegre, o único momento de exceção foi a estreia de António José, de Gonçalves de Magalhães, em 1838, pois "a arte dramática só fez legítimos progressos naquela época em que o Sr. Dr. Magalhães se uniu ao Sr. João Caetano: nessa época, todos os elementos se associaram e revestiram o palco cênico de toda sua dignidade" (In FARIA, 2001, p. 368). Mas a divergência não ocorre unicamente entre o ator e os literatos, a discordância - ou, mais exatamente, a culpa - recai sobre o "publico, [pois] sem público não há arte alguma que vigore, sem público não há artistas que progridam.”

Nós temos um discurso completamente diferente quando José de Alencar (In FARIA, 2001, p. 468) faz referência a Joaquim Heleodoro:

Quando acabei de escrever $O$ Rio de Janeiro, não supunha que ele estivesse destinado a subir à cena tão cedo, partilhava então a opinião geral de que os nossos teatros desprezavam as produções nacionais, e preferiam traduções insulsas, inçadas de erros e galicismo. [...] ela é inteiramente falsa a respeito do Ginásio. Esse teatro, que soube merecer as simpatias do público, é dirigido por um empresário que não sendo artista, tem contudo esse tato e discernimento necessário para a escolha das peças do seu repertório, e para a sua postura cênica.

A alteridade que separa o público do Ginásio dos outros teatros da capital é alvo dos comentários da época, como na crítica de Henrique César Muzzio (1831-1874) da peça Os mineiros da desgraça, de Quintino Bocaiuva (1836-1912):

Começamos a ter teatro nacional, isto é, há uma cena, pequena, acanhada, talada embora pelas mais sórdidas intrigas de bastidores, pelo mais feio egoísmo, onde os escritores brasileiros contemporâneos acham intérpretes das suas obras; e mais do que isso, uma plateia simpática, amiga, que lhes aplaude o estilo terso e cunhado pelo melhor padrão literário, que lhes entende as 


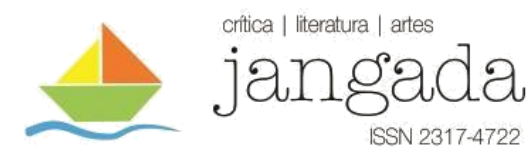

alusões finas e picantes, e que prefere o sal ático do epigrama dourado à chufa grossa, insultuosa e cínica, a que tanta festa fazem as plateias bestiais e que constitui o único talento dos chocarreiros de praça pública (In FARIA, 2001, p. 513).

Mas o que faz essa dramaturgia tão atrativa para os escritores e uma parte do público?

\section{AUTORREPRESENTAÇÃO BURGUESA E DIDATISMO MORAL}

Segundo Gengembre (1999, p. 143), é mais simples definir o teatro de Boulevard sociologicamente que dramaticamente: ele é o teatro da burguesia. Apoiando-se sempre em uma estrutura eficazmente bem amarrada, onde os conflitos são sempre resolvidos sem grandes surpresas, o público assiste ao triunfo de um teatro conformista, levemente provocador, que o insere nos debates do tempo, mas que adere à moral convencional do momento, chegando sempre à uma forma de consenso. Assim, "o efeito produzido é de uma asseptização. Esse teatro tranquiliza, conforta, confirma" ${ }^{8}$ ". Ele se transforma em "um verdadeiro espelho da classe dominante, ajudando-a a construir sua identidade, defendendo seus valores e finalmente celebrando seu triunfo sob o Segundo Império" 9" (BRUNET, 2005, p. 24), pois "tudo é destinado nesse teatro burguês, desde o seu nascimento, a fornecer ao espectador uma imagem do universo e dele mesmo revista e corrigida da maneira que lhe é mais conveniente ${ }^{10 "}$ (ABIRACHED, 1978, p. 122).

Ora, guardadas as devidas proporções, a evolução econômica e social do Brasil dos anos 1850 guarda várias semelhanças com o caso francês, no que se refere ao desenvolvimento das atividades econômicas urbanas e à ascensão de uma burguesia citadina. O período entre 1848 e a década de 1870 foi marcado por um progresso econômico sem precedente em escala mundial. É nesta época que uma minoria de países desenvolvidos se transforma em uma economia industrial e que uma série de inovações técnicas tornam possível uma extraordinária expansão do comércio internacional, ao qual se junta um vasto fenômeno de liberalização dos mercados (HOBSBAWN, 1982, p. 49-87). Esse boom econômico gera então uma verdadeira estandardização do mundo que ia além do quadro técnico e econômico, chegando, sobretudo

\footnotetext{
8 "L'effet produit est alors celui d'une aseptisation. Ce théâtre rassure, conforte, confirme."

9 “'...] un véritable miroir de classe dominante, l'aidant à construire son identité, prônant ses valeurs et célébrant finalement son triomphe sous le Second Empire."

10 “Tout est destiné dans le théâtre bourgeois, dès sa naissance, à fournir au spectateur une image de l'univers et de lui-même revue et corrigée à sa meilleure convenance."
} 


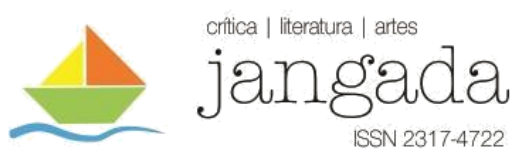

para as elites e classes médias urbanas, ao campo da cultura. Um certo otimismo toma conta desses grupos em escala mundial:

Não há dúvida de que os profetas burgueses de meados do século XIX olhavam para a frente procurando um mundo único e mais ou menos padronizado, onde todos os governos teriam o conhecimento das verdades da economia política e do liberalismo, levadas através do planeta por missionários impessoais mais poderosos que aqueles da cristandade ou do islamismo; um mundo refeito à imagem da burguesia, talvez mesmo onde, eventualmente, as diferenças nacionais viessem a desaparecer (HOBSBAWN, 1982, p. 84).

Não é por acaso, então, que o Segundo Império francês se transforma mais do que nunca no modelo das elites brasileiras, fato que acompanha o desenvolvimento do comércio mundial e as mudanças dos hábitos de consumo que, no Rio de Janeiro, podem ser observados pelas modas francesas disponíveis nas lojas da rua do Ouvidor ou pela ascensão do piano como fetiche de consumo e que será o instrumento europeu mais presente nas casas urbanas, substituindo a flauta, a rabeca e o violão (ALENCASTRO, 1997, p. 35-51).

Nós podemos ver, então, o que pode oferecer esse teatro em um momento que o Brasil passa por importantes mudanças sociais, com uma gradual, mas irreversível transição do trabalho escravo para o trabalho livre, com um desenvolvimento inédito das atividades urbanas e a aparição de uma classe média ou burguesa. Enfim, quando todo um mundo parece desaparecer, essa dramaturgia, que substitui os antigos heróis românticos por respeitáveis burgueses em tudo parecidos ao público, pode muito bem servir de modelo para uma sociedade em processo de reorganização de seus signos e valores. Além disso, num momento de confiança na ideia do progresso, o contato e a identificação com esse repertório são capazes de lisonjear a consciência e a autoestima de uma parte do público. Como mostra Jean-Claude Yon (2008, p. 8-9), o repertório francês é frequentemente um veículo de uma concepção "moderna" da sociedade - mesmo quando os autores dramáticos são considerados conservadores na França, eles podem ser apreciados pela vanguarda política e intelectual dos outros países pois eles difundem uma visão do homem e da sociedade que pode ser qualificada de "progressista" aos olhos do público estrangeiro. 


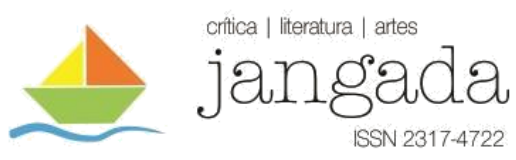

Uma característica, em particular, dessa dramaturgia se adapta perfeitamente a uma antiga preocupação dos homens de letras brasileiros: a dimensão pedagógica do teatro. Os dramas burgueses, conforme as teorias de Diderot, colocam o patético a serviço do ensinamento do espectador e os dramaturgos espalham lições de conduta em suas obras, característica que parece ser particularmente forte no teatro de Dumas fils. É a partir da obra deste que José de Alencar elabora sua ideia do teatro como um "daguerreótipo moral" (In FARIA, 2001, p. 471): o dramaturgo "fotografa" a realidade, principalmente a vida familiar e social, ao mesmo tempo em que ele a corrige, tendo por base os preceitos morais burgueses. Dessa forma, os homens de letras encontram um instrumento adequado para reforçar a antiga "missão" de intervenção na realidade e o teatro se transforma mais no que nunca em uma ferramenta pedagógica e de direcionamento do povo para o "progresso" ou a "civilização".

\section{ESCREVER SOBRE TEATRO}

Mas uma diferença importante deve ser observada entre a geração dos escritores reunidos em torno do Ginásio e aquela que nasceu em torno da revista Nitheroy em Paris: agora, nós estamos diante de homens de letras que trabalham efetivamente na imprensa.

Para Sébastien Rozeaux (2012, p. 613), a produção literária brasileira no Segundo Reinado parece uma literatura de transição entre o que ele chama de "Antigo Regime literário", onde predomina uma economia específica de mecenato e de favores pessoais, e um novo regime econômico onde predomina o jogo de oferta e demanda entre produtores e consumidores de bens culturais. Nesse processo, a imprensa tem um papel fundamental, pois ela oferece uma oportunidade de subsistência aos jovens autores em um momento em que os favores imperiais não dão mais conta de todas as ambições literárias.

O mais importante para os nossos propósitos, é notar que a imprensa oferece aos jovens escritores uma via para obter uma reputação no espaço público graças à polêmica literária, que serve de instrumento de distinção dentro do campo e que torna possível a promoção de uma concepção um pouco diferente da literatura e mesmo do estatuto do escritor na sociedade. É pela imprensa que José de Alencar lança uma bem-sucedida tentativa de dessacralização da obra de Gonçalves de Magalhães, as célebres Cartas sobre a confederação de Tamoios, que promove uma perturbação do equilíbrio dos poderes simbólicos no campo literário e faz do 


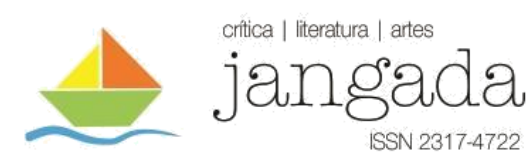

jovem autor o porta-voz de uma nova geração que procura se emancipar do modelo fundador do escritor orgânico (ROZEAUX, 2012, p. 643-655).

Enfim, tudo parece promover uma aproximação entre as funções de jornalista e de escritor. Segundo Sodré (1966, p. 220), os anos 1850 inauguram "a época dos homens de letras fazendo imprensa", e o próprio José de Alencar seria um “exemplo marcante de conjugação da literatura com a imprensa." Não é por acaso, então, que quase todos os escritores reunidos em torno do Ginásio começaram suas carreiras nos jornais antes de obter sucesso como autores de ficção.

Esses autores verão na imprensa um instrumento de afirmação de seus interesses e de seus projetos para o teatro brasileiro. Para José de Alencar, a responsabilidade do jornalista é tão grande quanto a do escritor e ambos fazem parte de uma mesma fraternidade que seria responsável pela construção desse monumento nacional que necessariamente é um trabalho coletivo, como ele explica em uma carta a Francisco Otaviano (1825-1889) publicada em 1857:

Quando se mostra a possibilidade de abrir uma carreira brilhante a todo aquele que Deus marcou com o selo da inteligência, para ser como o Assuerus da civilização, caminhando sempre e sempre para o futuro, sem parar diante da indiferença do presente, o homem que tem uma pena deve fazer dela um alvião, e cavar o alicerce do edifício que os bons filhos erguerão de sua pátria. Nós todos jornalistas estamos obrigados a nos unir e a criar o teatro nacional, criar pelo exemplo, pela lição, pela propaganda. É uma obra monumental que excede as forças do indivíduo, e que só pode ser tentada por muitos, porém muitos ligados pela confraternidade literária, fortes pela união que é a força do espírito, como a adesão é a força do corpo. (In FARIA, 2001, p. 469)

É sem surpresa, então, que o jornalista se torna um personagem dramático sob a pena desses escritores, frequentemente representado ao lado de artistas e de intelectuais, reunidos por uma missão comum, em oposição aos vilões. É o próprio José de Alencar (1860, p. XIV$\mathrm{XV})$ que sugere essa aproximação entre esses agentes no prólogo de As asas de um anjo - se o autor diz querer estabelecer uma oposição entre o jornalista Menezes e o artista Luiz, é evidente no seu comentário que os dois são investidos de uma mesma missão de intervenção na realidade social e que suas funções, ao invés de serem opostas, são, de fato, complementares: 


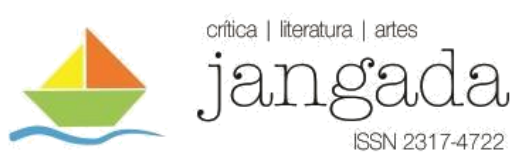

Menezes é a razão social encarnada em um homem; ele respeita a sociedade até mesmo nos seus prejuízos e nas suas exigências ridículas; por isso Carolina nos seus arrebatamentos, e nas suas blasfêmias contra a virtude, encontra sempre a palavra severa do jornalista que, às vezes esquecido do lugar em que está e das pessoas que o ouvem, deixa-se levar pelos seus sentimentos de honestidade. [...] [Ele] não procura corrigir a sociedade, não a discute como filósofo ou moralista, defende-a.

Luiz, artista pobre, que pelo seu trabalho chega à uma posição elevada, representa, ao contrário de Menezes, a razão absoluta, a razão superior à sociedade; esse sentimento que todos nós temos quando refletimos sobre alguns dos prejuízos do mundo, à primeira vista tão injustos.

Quem melhor dramatizou a figura do jornalista foi, provavelmente, Quintino Bocaiuva em Os mineiros da desgraça. Na peça, o Dr. Maurício assume o papel do raisonneur - esse personagem que o autor coloca em cena para explicar ao público a ideia por trás do que está sendo representado - que distribui lições em todas as direções. É ele que ajudará o jovem Paulo, personagem com traços de intelectual ${ }^{11}$ e que gosta também de disseminar sentenças moralizadoras, a desmascarar os usurários Venâncio e Vidal. Este último tem a ideia de fundar um jornal para facilitar os seus negócios: pela imprensa, ele atacaria todas as personalidades públicas que poderiam representar um entrave aos seus projetos. $\mathrm{O}$ agiota tenta convencer Maurício a se juntar ao seu plano, mas este responde com uma defesa apaixonada do trabalho do jornalista, que ecoa o trabalho do escritor e os princípios defendidos pelos dramaturgos da época:

Nós estamos num país e num tempo em que a imprensa deve ser tudo, porque tudo está por fazer! O jornal, entre nós, precisa ser sacerdote, quanto à religião; pai de família, quanto à educação moral; professor, quanto à instrução pública; estadista, quanto à gerência dos negócios políticos; general, nas coisas da guerra; agricultor, industrial, quanto aos melhoramentos materiais; juiz severo, nas coisas da magistratura; e até polícia para a descoberta dos criminosos. (In FARIA, 2006, p. 113)

\footnotetext{
${ }^{11}$ Para citar alguns exemplos tirados da peça: durante uma confrontação com o usurário Venâncio, este ironiza as "filosofias" de Paulo e exclama: "O senhor parece um bacharel!". O próprio Paulo diz, em uma conversa com o Dr; Maurício, que "[seus] amigos [o] chamam filósofo." Enfim, notamos que o personagem, após um período em Portugal, volta ao Brasil com um projeto, que ele tenta apresentar a um conselheiro do Império, de organização da colonização do país.
} 


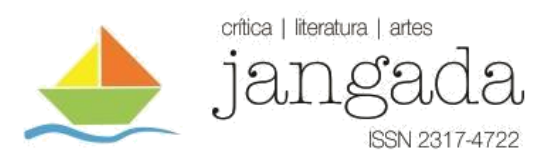

Em parte sob a influência desses escritores, a crítica teatral passa por uma lenta metamorfose ao longo da segunda metade do século XIX. Se as cartas anônimas de polêmica ou os escritos de diletantes (cf. GIRON, 2004) não desaparecem, assim como os folhetins que misturam vários assuntos, eles cedem pouco a pouco lugar a personalidades, frequentemente homens de letras conhecidos, que reivindicam um saber técnico para analisar o espetáculo e que, mesmo quando utilizam um pseudônimo, são facilmente reconhecidos ao menos dentro do meio literário. Nós vemos um exemplo dessa tendência em um folhetim - cujo autor não foi identificado pois a página está rasgada exatamente onde a assinatura deveria estar - de 1870:

Assinalar o que é bom, sem exagerar o que é mal nos parece o melhor ponto de vista da crítica, isto é, da que tem por fim criar e não da que mata para provar que é forte.

Não é raro ouvir maldizer por aí da crítica acerba [...] ou da nímia benevolência da imprensa em relação aos artistas e aos escritores.

Há certo fundo de justiça nas duas censuras.

A imprensa anônima, à tanto por linha, é quase sempre a que se encarrega do elogio bombástico e imerecido, ou da censura malévola, pessoal, repassada de fel e de inveja.

A outra imprensa, em geral, ou fica silenciosa, ou deixa cair dos bicos da pena [sic] alguma frase benévola, mas banal, que nem anima e nem desanima aquele a quem é dirigida.

Os artistas dramáticos sobretudo, sem outro guia que o capricho das plateias atiram-se com frenesi ao extravagante.

No cômico ou no sério só têm um alvo - ser aplaudidos [sic].

Daí a exageração de uns, a desenvoltura de outros, a decadência da cena, e o abandono do teatro dramático, o primeiro, o mais útil, o que ensina e diverte, às obras sem nome e sem intérpretes. (A Reforma, 23/06/1870)

É exatamente a crítica de Machado de Assis (2008, p. 307) ao trabalho de João Caetano, quando da morte deste em 1863:

As plateias soberanas, na distribuição dos sufrágios, não conhecem nem se empenham pela observância estrita do catecismo da arte. $\mathrm{O}$ artista as comovia e exaltava, e o aplauso fervente, ruidoso, espontâneo acolhia os rasgos de talento confiante de si.

Jangada| ano 9, nr. 17, jan/jun, 2021 | ISSN 2317-4722

67 | Pá g i n a 


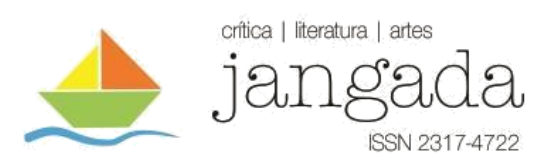

De sucesso em sucesso, verde de anos, convencido da própria capacidade, o artista deixou-se levar por essa onda, desassombrado de êmulos, embebido no presente e descuidoso do porvir. Tal foi o seu erro ou a sua fatalidade. Estava só na altura em que Deus o pusera, via correr os seus dias marcados por ovações, e, sem contradita nem competência, não puderam as suas faculdades adquirir o sumo grau da necessária perfeição.

Em resumo, se a afirmação da autoridade da crítica já era um topos comum na primeira metade do século XIX, ela se encontra agora misturada aos interesses dos escritores, seja em função do fato de que eles mesmos escrevem crítica, seja por causa de sua presença na imprensa, frequentemente em cargos de direção, o que influencia o debate e provoca uma convergência de interesses.

Assim, é sem surpresa que nós notamos uma evidente ressonância entre as opiniões encontradas na imprensa e aquelas dos homens de letras associados ao Ginásio. Este aparece então como o centro para onde convergem as forças que promoverão a regeneração, ou mesmo a criação, do teatro nacional. As peças representadas neste teatro, sobretudo aquelas de um autor brasileiro, seriam uma contribuição para a construção de um luminoso edifício monumental dedicado à glória nacional, como nós lemos em um comentário de José Lino de Almeida (18361888) sobre o drama Amor e Dinheiro, de Valentim José da Silveira Lopes (1830-?):

O drama nacional brasileiro surge afinal das trevas em que o desânimo, ou o descuido nosso ia o deixando mergulhado, e tão fundo que nem esperanças para uns havia de vê-lo um dia ocupar o seu lugar de legítimo e indisputável direito [...].

As esperanças bem fundadas que na alma me fizeram despertar os belos dramas dos Srs. Drs. J. De Alencar e Macedo, vistes vós transformar em crença, dando-nos Amor e Dinheiro. [...]

Felizmente o drama principia a ser compreendido entre nós; Alencar e Macedo aí estão para prova disso, e vós acabais como obreiro do progresso, que sóis, de levar a vossa valiosa coadjuvação a esse grande edifício que, malgrado muita gente, há de erigir-se e há de completar-se, porque meio ereto já vai ele (Correio Mercantil, 23/03/1862). 


\section{OS AUTORES DO GINÁSIO FRENTE AO PASADO DRAMÁTICO BRASILEIRO}

Nós vemos que quando esses autores falam em "criar" ou "regenerar" o teatro nacional, eles pensam em uma missão para o futuro: trata-se de erguer um monumento à glória nacional para ser contemplada pelas próximas gerações e animar os futuros poetas. Mas há também uma relação com o passado que é estabelecida, na medida em que eles se posicionam frente a uma situação dada pela história - toda "decadência" só pode existir em relação a um momento do passado.

O discurso de decadência é intimamente ligado, em parte, aos interesses dos diversos grupos profissionais que participam do evento teatral, interesses que implicam diferentes concepções sobre a cena e que, pela conversa sobre o declínio, disputam a autoridade para dizer o que é legítimo ou não em matéria de teatro. Esta disputa se manifesta também na escrita da história do teatro brasileiro, e principalmente sobre a sua "paternidade". Mesmo antes da aparição do Ginásio, esta questão já estava posta. Por exemplo, no artigo "O nosso teatro dramático", publicado na revista Guanabara em 1852, Araújo Porto-Alegre considerava a estreia de António José, em 1838, como o ponto alto da evolução dramática do país, pois foi o momento em que Gonçalves de Magalhães e João Caetano se uniram e, pela primeira vez, todos os elementos da cena estavam de acordo. No entanto, lendo o artigo, nós notamos que essa "união" era, na verdade, uma submissão do ator ao autor, pois Magalhães é apresentado como o mestre de João Caetano, e não somente no que se refere ao repertório, mas o próprio jogo cênico do ator só teria evoluído graças ao trabalho do escritor. Segundo Porto-Alegre, foi este que fez o ator trocar a "monótona declamação" pela "declamação onomatopeica". Além disso, seria o autor que o teria ensinado a dar vida às ideias do poeta pelos gestos e a utilizar os braços e os músculos da face. Mas o progresso da arte dramática não foi consolidado por culpa de João Caetano, que, deslumbrado, resolveu abandonar "seu voluntário mestre, o seu novo guia, o seu anjo benéfico, o seu gênio artístico" (In FARIA, 2001, p. 368).

Nos anos 1850 e 1860, quando Gonçalves de Magalhães já havia abandonado qualquer pretensão dramatúrgica e João Caetano, ocupando o principal teatro da corte e recebendo subvenções públicas, é cada vez mais acusado de exercer um monopólio maléfico sobre o teatro do Rio de Janeiro, nós encontramos outros comentários nesse sentido. Machado de Assis, em 1866, três anos após a morte do ator, continua a atribuir a paternidade do teatro nacional ao autor de António José.

Jangada | ano 9, nr. 17, jan/jun, 2021 | ISSN 2317-4722

69 | Pá g i n a 
O nome do Sr. Dr. Magalhães, autor de António José, está ligado à história do teatro brasileiro; aos seus esforços deve-se a reforma da cena, no tocante à arte da declamação, e as suas tragédias foram realmente o primeiro passo firme da arte nacional. Foi na intenção de encaminhar o gosto público, que o Sr. Dr. Magalhães tentou aquela dupla reforma, e se mais tarde voltou à antiga situação, nem por isso se devem esquecer os intuitos do poeta e os resultados da sua benéfica influência. (ASSIS, 2008, p. 404)

No entanto, Machado de Assis marca as suas diferenças, também: Gonçalves de Magalhães é um poeta talentoso, mas "puramente lírico", que procura a contemplação poética, mas não é um autor dramático. Assim, nós devemos ver suas peças como "o resultado de um esforço intelectual, empregado no trabalho de uma forma que não é a sua." De qualquer maneira, não há dúvida de que o líder da primeira geração romântica é "o fundador do teatro brasileiro" (ASSIS, 2008, p. 405).

De outro lado, nós temos Martins Pena (1815-1848), que apareceu pela primeira vez nos palcos também em 1838 com O juiz de paz na roça e, por conta disso, é considerado o fundador da comédia brasileira. Sobre este autor, é interessante notar que Sábato Magaldi (1962, p. 58) observa uma continuidade entre suas comédias e a produção dramatúrgica dos anos 1850 e 1860: as peças cômicas do comediógrafo seriam "o marco inicial da fixação dos costumes brasileiros, que são explorados por Joaquim Manuel de Macedo, José de Alencar, França Júnior ${ }^{12}$ e Artur Azevedo.” Magaldi vai ainda mais longe nesta aproximação quando ele diz haver no teatro de Martins Pena um propósito moralizador, um elogio implícito ou explícito aos bons costumes, tanto na vida pública como nos negócios privados, o que faria de suas comédias "uma escola de ética, antecipando esse papel que o teatro assumirá, conscientemente, mais tarde."

No entanto, os escritores do Ginásio têm uma visão bem diferente e rejeitam a obra de Martins Pena como modelo. José de Alencar, por exemplo, reconhece no autor "esse talento de observação, e essa linguagem chistosa, que primam na comédia, mas o desejo dos fáceis influiu no seu espírito, e o escritor sacrificou talvez suas ideias ao gosto pouco apurado da época" (In

12 Se João Roberto Faria (1993, p. 244-249), não considera França Júnior um “realista”, o próprio autor, que teve algumas de suas peças representadas no Ginásio, assume a inspiração desse repertório no começo de sua carreira. Jangada | ano 9, nr. 17, jan/jun, 2021 | ISSN 2317-4722 


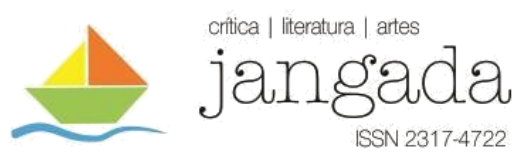

FARIA, 2001, p. 470). Machado de Assis (2008, p. 412) condena a obra de Martins Pena por causa do registro, longe da alta comédia idealizada pelos realistas. Na sua opinião, a verdadeira comédia brasileira teria começado com Rio de Janeiro, verso e reverso, de Alencar: "até então a comédia brasileira não procurava os modelos mais estimados; as obras do finado Pena, cheias de talento de boa veia cômica, prendiam-se intimamente às tradições da farsa portuguesa."

Desse modo, esses autores reivindicam a supremacia do homem de letras sobre o teatro brasileiro, em detrimento de outros profissionais da cena, principalmente os empresários e os atores, representados na figura de João Caetano, ao mesmo tempo em que eles se diferenciam da geração anterior, não somente do ponto de vista estilístico, mas no sentido de que esta teria fracassado na missão de criar o teatro nacional, missão que, agora, caberia à geração que se diz "realista".

\section{OS REALISTAS-ROMÂNTICOS: REPRESENTAÇÕES DO HOMEM DE LETRAS NO TEATRO}

No entanto, a denominação "realista" pode se mostrar enganosa, pois não devemos imaginar que, do ponto de vista literário, nós estamos falando de Balzacs ou de Flauberts. Esses escritores "realistas" são, na verdade, românticos e escreveram mesmo algumas das obras mais emblemáticas do romantismo brasileiro. É por isso que seus escritos e peças são cheios de representações bem românticas sobre o trabalho do escritor ou sobre a figura do artista, e é notável a frequência que este é um dos personagens principais de suas obras dramáticas, quase sempre do lado do bem. Vejamos, por exemplo, a peça Luxo e Vaidade, de Joaquim Manuel de Macedo, representada no Ginásio no dia 23 de setembro de 1860, onde o jovem pintor Henrique se apaixona por sua prima Leonina, jovem burguesa de bom coração, mas fútil e superficial por conta da educação que recebeu de seus pais. Ela, que ignora suas próprias origens familiares e não sabe que o pai de Henrique é também o seu tio, se sente atraída pelo pintor quando o encontra pela primeira vez, mas ela o repele quando descobre sua profissão - mesmo que ele tenha estudado na Europa - e, ainda por cima, que ele é filho de um simples artesão. A condição do artista aparece várias vezes ao longo da peça, como quando o jovem pintor se lamenta do desprezo social do qual ele é vítima: 


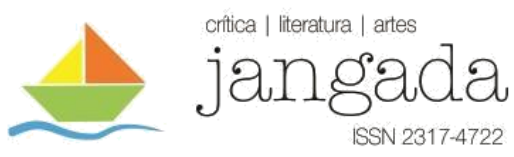

Miserável orgulho de artista!... artista!... de que te vale essa palheta, que amas como um cetro, essa glória, com que sonhas incessantemente? De que te vale o gênio, artista?... oh!... quem me dá um cofre de ouro por essa palheta, que me custou tantos anos de fadigas? Quem me dá um cofre de ouro pela glória de meus sonhos, pelo talento que me inflama?... Oh... vãs quimeras!... a glória é uma ilusão! O talento é nada! O gênio é a túnica de Nesso, o merecimento, a probidade, a sabedoria são mentiras! Há só uma grande verdade, é o ouro! (MACEDO, 1865, vol. I, p. 107)

Henrique encontra um aliado na figura de Anastácio, seu tio, rude camponês, padrinho de Leonina, que despreza a sociedade superficial na qual vive a família de seu irmão e parece ser o único capaz de compreender o valor da arte. É ele quem pagou os estudos de Henrique na Europa. Na peça, ele exerce a função de raisonneur e procura encorajar o jovem pintor - "sê portanto orgulhoso com esses que em sua soberba desprezam o artista que vale mil vezes mais do que eles" (MACEDO, 1865, p. 43) - e intercede junto a Leonina e tenta dar algumas lições à jovem burguesa: "o verdadeiro artista já é nobre de si mesmo, Leonina; e a sua nobreza lhe vem de Deus, que acendeu em seu espírito a flama do gênio.” (MACEDO, 1865, p. 49)

O jovem artista ou o intelectual apaixonado é frequentemente o protagonista das peças desses escritores, condição pela qual ele pode ser rejeitado pela sua amada - pois ela, que representa a sociedade, prefere um outro candidato mais rico, escolha que provoca a sua queda e, no futuro, o seu arrependimento - ou, ao contrário, esta é uma mulher de exceção que reconhece o valor do artista, mas as convenções sociais ou os inimigos do protagonista são obstáculos à realização do amor do casal. No primeiro caso, nós temos a dupla Luiz e Carolina, em As asas de um anjo, de Alencar:

LUIZ - Não me lembro. Seu pai e sua mãe a adoravam; tinha um primo, pobre artista, que a amava loucamente.

CAROLINA - A amava?...

LUIZ - Sim, senhora. Era ela que lhe dava a ambição; era esse amor que o animava no seu trabalho, e que o fazia adquirir uma instrução que depois o elevou muito acima do seu humilde nascimento. (ALENCAR, 1860, p. 67) 
No segundo caso, nós temos, na peça $O$ Crédito, do mesmo autor, Rodrigo e Julieta. Esta defende o primeiro durante uma conversa com sua amiga, a frívola Cristina:

CRISTINA - Rodrigo!... Não é um moço que chegou há pouco da Europa? Mamãe conhece-o.

JULIETA - É esse mesmo. Seu pai preferiu gastar o pouco que possuía em darlhe uma bela educação, e mandou-o estudar na Alemanha.

CRISTINA - Ele é pobre, então?

JULIETA - Pobre de dinheiro, mas rico de inteligência.

CRISTINA - Ora, que vale essa riqueza?

JULIETA - Mais do que pensas. Não é só o dinheiro que é riqueza, Cristina. A inteligência vale mais do que o ouro. (ALENCAR, 1959, p. 139-140)

A superioridade do intelectual é afirmada pelo próprio Rodrigo, durante uma conversa com Pachedo, o pai de Julieta:

Dirigi-me a alguns negociantes e capitalistas, apresentei-lhes a minha ideia para a construção de um caminho de ferro. Aceitaram; formamos uma sociedade; eles deram o seu capital em dinheiro, eu dei o meu em inteligência e trabalho. Parece-me que se neste contrato há superioridade, não é decerto daqueles que forneceram a moeda metálica, fabricada pelos homens, mas sim da parte daquele que contribuiu com a moeda universal criada por Deus. (ALENCAR, 1959, p. 172)

Se o herói é um homem cultivado, seus inimigos se notabilizam pelo desprezo pela inteligência e são, sobretudo, homens pragmáticos. Neste caso, o usurário Macedo faz questão de desdenhar os homens de espírito:

O pensamento é um inimigo do progresso e da felicidade humana. Se um homem pensasse antes de entrar num vapor, lembrava-se da caldeira e não embarcava, se pensasse nos desastres dos caminhos de ferro, não viajaria senão a pé; se pensasse nos prejuízos, não comprometia seus capitais em transações. Todo o homem que pensa é estúpido; porque não há estupidez 


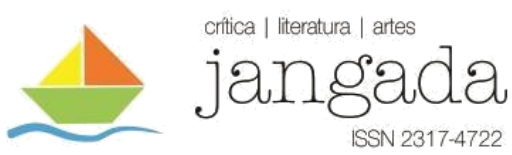

maior do que ser pobre, podendo ficar rico em um momento. (ALENCAR, 1959, p. 187)

Este é também o caso de Beatriz, personagem da peça de inauguração do Ginásio, $O$ Primo da Califórnia, de Joaquim Manuel de Macedo. Bela na sua juventude, ela não aceita a situação na qual se encontra na sua velhice: empregada de um músico, o pobre Adriano Genipapo. Ela passa toda a primeira parte da peça resmungando contra o músico... até o momento em que ela descobre a falsa notícia segundo a qual Adriano teria recebido uma fortuna como herança de um primo. No começo da peça, ela exprime sua incredulidade vendo o amor de Celestina pelo artista, que é bela e jovem e poderia, portanto, encontrar facilmente um marido rico. Esta responde com sua admiração pelo trabalho do jovem músico. Beatriz a ironiza: "Sim... sim... ideias romanescas, poesias, e pensamentos generosos; mas o diabo me leve se a sra. for capaz de fazer ferver uma panela no fogo com um soneto, ou com uma ideia generosa." (MACEDO, 1865, t. I, p. 157)

Todas essas representações ecoam uma ideia subjacente de todo o discurso sobre a decadência do teatro: o homem de letras é um ser excepcional cuja missão é guiar as massas, mas, por diversas razões, ele não chega aos seus fins. Uma jactância particular ao meio literário brasileiro e que encontra suas origens na própria formação da literatura nacional (CÂNDIDO, 1959). Machado de Assis (2008, p. 240), por exemplo, lamenta que "o autor dramático não é ainda, entre nós, um sacerdote.” A imagem que aparece de todo esse debate, é aquela do letrado isolado no seio de uma sociedade por demais positiva e materialista para dar-se conta das verdades anunciadas pelos poetas - uma imagem que nós encontramos em António José, de Gonçalves de Magalhães, que tematiza a figura do gênio incompreendido e perseguido através da figura do dramaturgo que dá nome à peça, que foi preso e morto pela Inquisição. Henrique César Muzzio, protesta contra uma sociedade que "moralmente baixa numa progressão lastimosa." Ele opõe os "paladares melindrosos que se revoltam contra os manjares por demais suculentos" e que se satisfazem somente com "comédia chocarreira e insípida", aos “inteligentes, aos pensadores", aos quais deve-se nutrir com "diversa iguaria” (In FARIA, 2001, p. 523-524). As peças desses homens de letras dramatizam em certa medida sua própria situação, seja ela real ou puramente retórica, pela figura de heróis intelectuais ou amigos da inteligência que procuram mudar seu meio social da mesma forma que o autor dramático se coloca como um educador do público. Esses personagens aparecem então como seres 


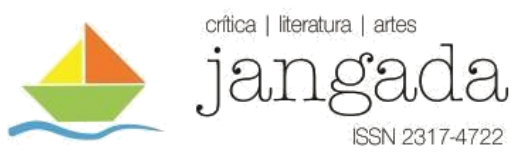

excepcionais sob uma cobertura de simples burgueses que devem enfrentar a indiferença social e mesmo o governo - por exemplo, quando Paulo, em Os mineiros da desgraça, procura mostrar seu projeto de uma estrada de ferro a um conselheiro do Império, este o ignora.

Dessa maneira, o Ginásio aparece como uma espécie de cidadela onde uma sociedade do espetáculo de elite se reune e que, durante alguns anos, serve de abrigo a homens de letras que, ao mesmo tempo em que lamentam o estado do teatro nacional e lançam acusações contra o mundo exterior, podem ainda guardar uma certa esperança de um futuro melhor, da mesma maneira que, nas suas peças, os personagens do lado do bem terminam sempre vencedores e a ordem do mundo é restabelecida. O Ginásio será então o foco a partir do qual será lançado um movimento de renovação não somente do teatro, mas de toda nação, um movimento que recolocará o país no caminho do progresso:

O teatro, como o têm dito e repetido juízes dos mais peritos, é o verdadeiro termômetro da civilização de um povo. Fundemos, pois, o nosso; acabemos com o industrialismo artístico que abastarda, entorpece, esteriliza os melhores engenhos e entrega a musa e os seus cultores aos caprichos da multidão ignorante e embrutecida pelas tradições em que a educaram (MUZZIO in FARIA, 2001, p. 526)

\section{CONSIDERAÇÕES FINAIS}

Com esse artigo, nosso objetivo era não somente lançar luz sobre um período - já razoavelmente bem estudado, diga-se de passagem - da história do teatro brasileiro, mas sobretudo propor uma nova interpretação para a escrita dessa história, que recoloca o teatro brasileiro no contex to de uma história global ${ }^{13}$ do teatro pelo estudo de um caso específico: a adoção do teatro de boulevard francês pelos homens de letras brasileiros nas décadas de 1850 e 1860. No entanto, é preciso evitar modelos redutores como aqueles que pregam uma relação de "centro-periferia"

\footnotetext{
${ }^{13} \mathrm{~A}$ « mundialização » ou a « globalização » é um tema onipresente na pesquisa em ciências humanas das últimas décadas. Nascida como uma questão econômica, ela se transformou em um problema incontornável de todas as disciplinas sociais, a história inclusa, e, particularmente, a história contemporânea, onde o tema produziu várias declinações como "história global", "transnacional" ou "conectada". Os estudos culturais não escapam a essa tendência e é comum falar hoje em dia de "mundialização cultural" (Cf. LECLERC, 2000; POIRRIER, 2008). No que concerne as artes do espetáculo, alguns trabalhos recentes procuram estabelecer um novo quadro de referência e fazer análises que ultrapassam as fronteiras nacionais, seja por uma perspectiva comparativa (Cf. CHARLE, 2008; MOISAND, 2013), seja pela abordagem das "circulações" ou das "transferências" entre os países (Cf., por exemplo, BALMER, 2012; COMPAGNON, FLÉCHET, SOARES, 2017.).
} 


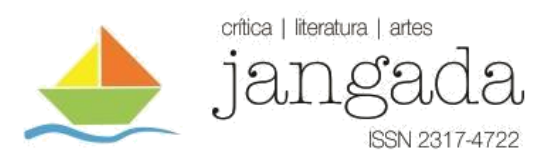

onde as produções daquele são automaticamente adotadas nesta, segundo um esquema de dominação e fluxo unidirecional, assim como termos simplistas como "influência" (Cf., por exemplo, TORRES NETO, 1996), de onde o interesse em se pensar em termos de uma "transferência cultural”. De fato, a própria noção da "decadência" do teatro e da necessidade de sua regeneração já é, em si, um convite para repensar a história das artes dramáticas nacionais, uma vez que esse discurso está longe de ser uma particularidade brasileira, pois nós o encontramos em praticamente todos os países do mundo onde há um teatro profissional, a começar pela França, que, no entanto, era o principal centro teatral mundial do século XIX (POLLETI, YON, 2018; GOETSCHEL, 2020).

Nós abordamos aqui principalmente o ponto de vista dos autores da época, que viam o teatro como uma parte de sua missão de erguer esse "grande monumento nacional" que deveria ser a literatura brasileira. Esta deveria ser, ao mesmo tempo nacional e moderna: ela deveria representar (ou criar) a nacionalidade ao mesmo tempo em que persegue, segundo Rozeaux (2012, p. 221) "esse princípio instável, [que] se baseia na crença, forte entre os escritores, de uma literatura 'contemporânea', a fim de entrar no tempo literário, garantia de salvação das letras nacionais ${ }^{14}$ ". O autor se baseia nas ideias de Pascale Casanova (2008, p. 135-156), segundo as quais a unificação do espaço literário mundial supõe o estabelecimento de uma medida comum do tempo, que é, ao mesmo tempo, um lugar situado no espaço, o centro de todos os centros, e um ponto a partir do qual se mede o tempo próprio da literatura. É esse centro, que a autora chama de "meridiano de Greenwich", o produtor do tempo literário e detentor do título de capital mundial da literatura. Dessa maneira, todos os escritores que se encontram afastados da capital, ou, para ser mais preciso, de Paris, fazem referência, conscientemente ou não, a esse "presente" que define as obras legítimas.

Silvia Cristina Martins de Souza e Silva (2000, p. 15) defende que a "função social da qual estava revestida a dramaturgia realista foi a substância que atraiu os literatos levando-os a considerar o teatro uma peça-chave para a construção de uma almejada identidade cultural e de educação da sociedade”. O problema com essa perspectiva é colocar os usos que se fazem desse repertório como causa de sua adoção, supondo que o sucesso de sua recepção foi resultado de uma coincidência entre a concepção de literatura dos autores brasileiros e as "propostas" da "escola" realista francesa, como se houvesse existido um movimento literário com propostas

14 “[...] ce principe instable, repose sur une croyance, forte chez les écrivains, en une littérature 'contemporaine', afin d'entrer le temps littéraire, garant du salut des lettres nationales."

Jangada | ano 9, nr. 17, jan/jun, 2021 | ISSN 2317-4722

76 | Pá g i n a 


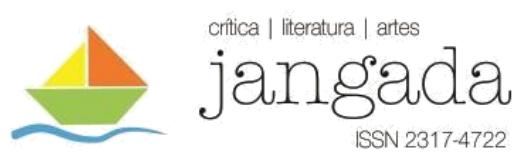

bem definidas com esse nome. Além disso, o uso do teatro como elemento de construção da identidade é uma questão que já aparece bem antes do Ginásio - vide a recuperação da figura de António José por Gonçalves de Magalhães como um dramaturgo nacional -, assim como o seu objetivo de educação popular.

Mais interessante é uma abordagem que analisa as dinâmicas internas do campo literário carioca e as transformações pelas quais este passa na segunda metade do século XIX em função das transformações sociais e econômicas que ocorrem em escala tanto local como mundial. Nesse sentido, o repertório dito "realista" aparece, então, como uma oportunidade, aberta por Joaquim Heleodoro, para jovens escritores excluídos da economia do mecenato e dos favores imperiais que regia até então a produção cultural carioca. Isso explica, em parte, essa curiosa decalagem temporal: autores românticos que são, ao mesmo tempo, dramaturgos "realistas". E não podemos negligenciar o fato de que para os "jogadores" das nações periféricas - aquilo que Pascale Casanova (2008, p. 139-152) chama de "cosmopolitas excêntricos" - que procuram seu espaço na "república mundial das letras", efetuar a transferência das revoluções que ocorrem nos centros literários mundiais em direção aos seus espaços literários nacionais, é uma importante maneira de alcançar a consagração dentro de seus próprios espaços nacionais, ao mesmo tempo em que eles promovem uma atualização de suas próprias literaturas e dão, dessa forma, trunfos para os "jogadores" nacionais entrar na competição mundial e, simultaneamente, reforçam a hegemonia e o poder de consagração da capital mundial. Nesse sentido, o que os autores do Ginásio estavam fazendo era inserir a história do teatro nacional dentro da história mundial do teatro, que tem como referência, evidentemente, o teatro parisiense.

No entanto, como observado por Michel Espagne (2013), toda passagem de um objeto cultural de um contexto a outro gera uma dinâmica de ressemantização e de transformação do seu sentido. O que nós vemos é que os autores brasileiros fizeram uma leitura bem particular da história dramática francesa e, portanto, mundial (para a concepção da época), que diz respeito menos ao teatro francês que às questões que estão sendo debatidas na sociedade brasileira da época e seu teatro. Christophe Charle (2010, p. 55) já alertava que o principal obstáculo para a realização de uma transferência reside menos na produção do que na recepção: o problema é criar o desejo de ler, de ver ou de escutar no leitor ou no espectador, o que significa que é preciso que o produto estrangeiro encontre lugar no espaço de representações do país receptor, que é estruturado pela cultura local e pelas relações históricas com a cultura externa 


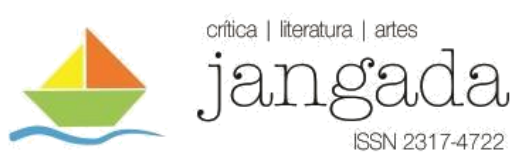

de onde vem esse novo bem. Se a dramaturgia dita realista prosperou no Brasil por alguns anos, foi porque ela encontrou na sociedade brasileira da época um conjunto de fatores que fizeram dela viável, que incluem as transformações sociais da época, o alargamento do mercado editorial e de diversões que resultam, por sua vez, em desequilíbrios do campo literário e mudanças na concepção do trabalho intelectual. Os homens de letras, por sua vez, aproveitarm a plasticidade desse produto cultural e o ressignificaram segundo os processos que estão ocorrendo dentro de seu próprio campo e de uma certa tradição nacional, o que nós vemos, por exemplo, nas representações da figura do intelectual em suas peças. Assim, eles criaram uma história do teatro nacional dentro de uma história global e se posicionaram em relação ao seu passado ao mesmo tempo em ruptura e em continuidade, fazendo da dramaturgia brasileira, ao mesmo tempo, universal e particular.

\section{REFERÊNCIAS BIBLIOGRÁFICAS}

ABIRACHED, R. La Crise du personnage dans le théâtre moderne. Paris : B. Grasset, 1978. ALENCAR, J., As asas de um anjo. Rio de Janeiro: Editores Soares \& Irmão, 1860. Obra completa, vol. 4. Rio de Janeiro: J. Aguilar, 1959.

ALENCASTRO, L. "Vida privada e ordem privada no império". In: ALENCASTRO, L. e F. NOVAIS (org.), História da vida privada no Brasil 2: Império: a corte e a modernidade nacional. São Paulo: Companhia das Letras, 1997.

ASSIS, M. Do teatro: textos críticos e escritos diversos. Edição de João Roberto Faria. São Paulo: Perspectiva, 2008.

BALMER, C., "Histórias globais do teatro: modernização, esferas públicas e redes teatrais transnacionais." In WERNECK, M. E REIS, A. (org.) Rotas de teatro: entre Portugal e Brasil. Rio de Janeiro: 7Letras, 2012, p. 203-219

BRUNET, B. Le théâtre de Boulevard. Paris: Armand Colin, 2005.

CÄNDIDO, A. Formação da literatura brasileira: momentos decisivos. São Paulo: Livraria Martins, 1959.

CASANOVA, P. La république mondiale des lettres. Paris : Éditions du Seuil, 2008.

CHARLE, C. Théâtres en capitales: naissance de la société du spectacle à Paris, Berlin, Londres et Vienne, 1860-1914. Paris: A. Michel, 2008.

Comparaisons et transferts en histoire culturelle de l'Europe. Quelques réflexions à propos de recherches récentes. Les cahiers SIRICE. Paris, v. 1, n 5, p. 51-73, 2010. Disponível em : < https://www.cairn.info/revue-les-cahiers-irice-2010-1-page-51.htm >. Visita em: 25/05/2021.

COMPAGNON, O, A. FLÉCHET, G. SOARES. Écrire une histoire culturelle transatlantique (XVIIIe-XXIe siècles) : enjeux, défis et méthodes. Diogène. Paris, v. 2-3-4, n 258-259-260, p. 


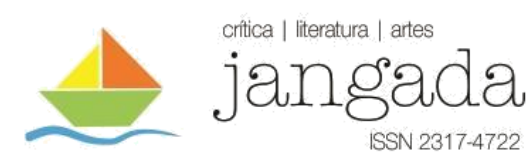

237-250 2017. Disponível em : <https://www.cairn.info/revue-diogene-2017-2-page237.htm>. Visita em: 25/05/2021.

DANGER, P. Émile Augier ou Le théâtre de l'ambiguïté: éléments pour une archéologie morale de la bourgeoisie sous le Second Empire. Paris: 1'Harmattan, 1998.

ESPAGNE, M. La notion de transfert culturel. Revue Sciences/Lettres. Paris, n. 1, 2013. Disponível em: < https://journals.openedition.org/rsl/219 >. Acesso em: 25/05/2021.

FARIA, J. José de Alencar e o teatro. São Paulo: Perspectiva, 1987.

O Teatro realista no Brasil: 1855-1865. São Paulo: Perspectiva, 1993.

Ideias teatrais: o século XIX no Brasil. São Paulo: Perspectiva, 2001.

(org.) Antologia do teatro realista. São Paulo: Martins Fontes, 2006.

FARIA, J. e J. GUINSBURG (orgs.). História do teatro brasileiro, vol. 1. São Paulo:

Perspectiva, 2012.

GENGEMBRE, G. Le théâtre français au XIXe siècle, 1789-1900. Paris: Armand Colin, 1999.

GIRON, L. Minoridade crítica : a ópera e o teatro nos folhetins da corte, 1826-1861. Rio de Janeiro, São Paulo: Ediouro, Edusp, 2004.

GOETSCHEL, P. Une autre histoire du théâtre. Discours de crise et pratiques spectaculaires. France, XVIIIe-XXIe siècle. Paris : CNRS Éditions, 2020.

HASHEM, H. Émile Augier, Alexandre Dumas fils, Victorien Sardou : dramaturgie du savoirvivre sous le Second Empire. Paris: l'Harmattan, 2015.

HASLÉ, L. La Direction d'Adolphe Lemoine-Montigny au Théâtre du Gymnase de 1844 à 1880. 2020, 595 p. Thèse - Université Paris sciences et lettres.

HOBSBAWN, E. A Era do capital: 1848-1875. Rio de Janeiro: Paz e Terra, 1982.

LECLERC, G. La mondialisation culturelle : les civilisations à l'épreuve. Paris: Presses universitaires de France, 2000.

LIOURE, M. Le Drame: de Diderot à Ionesco. Paris: Armand Colin, 1999.

MACEDO, J. Theatro do Doutor Joaquim Manoel de Macedo. Rio de Janeiro: H. Garnier, 1865.

MAGALDI, S. Panorama do teatro brasileiro. São Paulo: Difusão europeia do livro, 1962.

MOISAND, J., Scènes capitales : Madrid, Barcelone et le monde théâtral fin de siècle. Madrid: Casa de Velázquez, 2013.

POIRRIER, P. L'histoire culturelle: un «tournant mondial » dans l'historiographie? Dijon: Editions Universitaires de Dijon, 2008.

POLLETI, D e J. YON. Le spectacle dans une modernité périphérique. La « décadence » du théâtre brésilien dans un contexte global (XIX ${ }^{\mathrm{e}}$ siècle-années 1920). Passages de Paris, v. 16, p. 86-106, 2018. Disponível em: <http://www.apebfr.org/passagesojs/index.php/pp/article/view/70 >. Visita em: 20/05/2021. REIS, D. José de Alencar e o teatro: um romântico realista. Acta Scientiarum. Language and Culture. Maringá, v. 35, n. 1, p. 63-73, 2013. Disponivel em $<$ https://periodicos.uem.br/ojs/index.php/ActaSciLangCult/article/view/10475>. Visita em: 25/05/2021. 


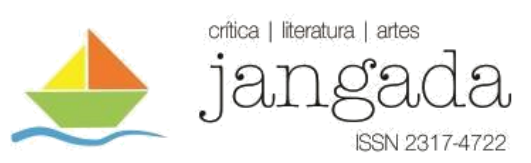

ROZEAUX, S. La genèse d'un " grand monument national " : littérature et milieu littéraire au Brésil à l'époque impériale (1822-1880). 2012. 3 vol., 801, 198 p. Tese - Université Charles de Gaulle-Lille III.

SANTANA, C. Poética do drama e esclarecimento: Diderot, teatro e educação. A Palo Seco. São Cristóvão, n. 10, p. 94-101, 2017. Disponível em https://seer.ufs.br/index.php/apaloseco/article/view/8261. Visita em 15/07/2021.

SCANDAROLLI, D. "Le théâtre d'Eugène Scribe sur la scène de la Cour impériale brésilienne (1840-1848)". In: BARA, O. e J. Yon (org.). Eugène Scribe: un maître de la scène théâtrale et lyrique au XIX $X^{e}$ siècle. Rennes: Presses universitaires de Rennes, 2016.

SILVA, S. As noites do Ginásio: teatro e tensões culturais na Corte (1832-1868). 2000, 315 p. Tese - Universidade Estadual de Campinas.

SODRÉ, N. História da imprensa no Brasil. Rio de Janeiro: Civilização Brasileira, 1966.

SOUTO-MAIOR, V. "Gabriela e Cancros Sociais: a estratégia palimpséstica no teatro de Maria Angélica Ribeiro.” In: AQUINO, R. e S. MALUF (org.), Dramaturgia e Teatro. Maceió: edUFAL, 2004.

SOUZA, S. As noites do Ginásio: teatro e tensões culturais na Corte, 1832-1868. Campinas: Editora da UNICAMP, 2002.

TORRES NETO, W. Influence de la France dans le théâtre brésilien au XIX ${ }^{e}$ siècle : l'exemple d'Arthur Azevedo. 1996, 395 p. Tese - Université Paris III-Sorbonne Nouvelle

YON, J. Eugène Scribe : la fortune et la liberté. Saint-Genouph: A.-G. Nizet, 2000.

YON, J. "Introduction". In : YON, J. (org.) Le théâtre français à l'étranger au XIXe siècle : histoire d'une suprématie culturelle. Paris : Nouveau Monde, 2008.

YON, J. "Une triade et un vétéran: Augier-Dumas fils-Sardou et Scribe sous le Second Empire." In: YON, J. (org.), Les spectacles sous le Second Empire. Paris: Armand Colin, 2010. 